\title{
Stability Study Type Terminology
}

National Cancer Institute

\section{Source}

National Cancer Institute. Stability Study Type Terminology. NCI Thesaurus. Code C96079.

Terminology developed to support Study Types within the Stability Data Standards. 